\title{
ESTIMASI PENDAPATAN ASLI DAERAH DAN PERTUMBUHAN EKONOMI JAKARTA PRA-PANDEMIC COVID -19
}

\author{
Yurianto \\ Widyaiswara Ahli Madya \\ Badan Pengembangan Sumber Daya Manusia Provinsi DKI Jakarta \\ yuribpsdm@gmail.com
}

Dikirim: 17 September 2020; Direvisi: 30 November 2020; dipublikasikan: 24 Desember 2020

\begin{abstract}
ABSTRAK
Pandemic Covid-19 merupakan krisis kesehatan yang berimbas pada perekonomian. Dinamika perekonomian mempengaruhi Pendapatan Asli Daerah (PAD) dan Pertumbuhan ekonomi. Tujuan kajian ini adalah melakukan estimasi nilai Pendapatan Asli Daerah dan estimasi pertumbuhan ekonomi Tahun 2020 jika tanpa ada Pandemic Covid-19. Metode yang digunakan adalah model persamaan simultan (Simultaneous Equation Model), Model persamaan simultan terbagi menjadi lima blok dan terdiri dari 32 persamaan. Lima blok tersebut adalah Blok Fiskal Penerimaan Daerah, Blok Fiskal Pengeluaran Daerah, Blok PDRB, Blok Inflasi, dan Blok Indikator Sosial. Jika tidak ada pandemic Covid-19, diperkirakan total Pendapatan Asli Daerah pada tahun 2020 sebesar Rp.64,26 triliun dan ekonomi Jakarta tumbuh 5,22 persen.
\end{abstract}

Kata Kunci: Covid 19, Pendapatan Asli Daerah, Pertumbuhan Ekonomi

\begin{abstract}
The Covid-19 pandemic is a health crisis that has an impact on the economy. Economic dynamics affect Regional Original Income $(P A D)$ and economic growth. The purpose of this study is to estimate the value of Regional Original Income and estimate economic growth in 2020 if there is no Covid-19 Pandemic. The method used is a simultaneous equation model (Simultaneous Equation Model). The simultaneous equation model is divided into five blocks and consists of 32 equations. The five blocks are the Regional Revenue Fiscal Block, the Regional Expenditure Fiscal Block, the PDRB Block, the Inflation Block, and the Social Indicator Block. If there is no Covid-19 pandemic, it is estimated that the total Regional Original Revenue in 2020 will be Rp. 64.26 trillion and the economy of Jakarta will grow 5.22 percent.
\end{abstract}

Keyword: Covid 19, Regional Original Income, Economic Growth. 
Volume 12, No. 3, Desember 2020, pp. 230-242

e-ISSN: $2502-5449$

p-ISSN: 2085-2266

DOI : 10.30998/sosioekons.v12i3.7568

\section{PENDAHULUAN}

Undang undang No 23 tahun 2014 tentang Pemerintahan Daerah merupakan salah satu landasan hukum penyelenggaraan pemerintahan daerah. Pada era ini yang sering disebut dengan era otonomi daerah dan desentralisasi fiscal, pembangunan daerah sangat tergantung pada pertumbuhan dan perkembangan perekonomian daerah. Perkembangan dan pertumbuhan perekonomian daerah membutuhkan kondisi iklim usaha yang sehat, sumber daya manusia dan sumber daya ekonomi yang mencukupi dan memadai. Menurut penelitian Tiebout (1956) dalam Rodriguez-Pose dan Kroijer (2009) bahwa salah satu keuntungan dari desentralisasi fiskal adalah bahwa desentralisasi akan meningkatkan efisiensi ekonomi pemerintah lokal karena pemerintahnya akan lebih mampu memberikan layanan yang lebih baik kepada masyarakatnya. Jika demikian, maka perekonomian dan kesejahteraan daerah diharapkan akan lebih inovatif, kreatif maju, sustain dan berketahanan. Namun dengan perkembangan sekarang kinerja perekonomian daerah terlebih lagi Jakarta tentu akan terpengaruh secara langsung oleh adanya wabah pandemic covid -19. Variable perekonomian Jakarta lebih kompleks dari daerah lain. Berdasarkan undang undang No 29 tahun 2007 bahwa otonomi daerah di Jakarta diletakan pada tingkat Provinsi bukan pada tingkat Kabupaten atau kota. Pemerintah Provinsi menjadi sangat sentral dan strategis dalam perencanaan dan penganggaran. Kontribusi perekonomian Jakarta dalam lingkup nasional mencapai 17,7 hingga 18 persen dari keseluruhan produk domestik bruto nasional (bisnis.tempo.co.,2020) . Selain itu, Jakarta merupakkan kota yang mempunyai multi fungsi. Dengan demikian permasalahan ekonomi lebih komplek, lebih besar, dan lebih sensitive terhadap perubahan. Untuk itu, diperlukan usaha lebih sistematis untuk memperoleh data yang akurat dan akuntabel.

Indikator kinerja perekonomian daerah bisa direpresentasikan dengan beberapa indikator, antara lain kinerja fiskal daerah, pertumbuhan ekonomi, Nilai PDRB, jumlah penduduk miskin, penyerapan tenaga kerja,dan angka IPM. Indikator kinerja perekonomian tersebut merupakan kelompok indikator yang sering digunakan untuk mengukur perkembangan tingkat kesejahteraan rakyat suatu daerah.

Dari beberapa ukuran tersebut, indikator pertumbuhan ekonomi merupakan indikator kunci utama dalam peningkatan kesejahteraan rakyat. Berdasarakan hasil kajian Bappenas (2017) bahwa berkembangnya perekonomian daerah, akan berdampak positif terhadap penyerapan tenaga kerja, peningkatan PAD dan lain sebagainya yang pada akhirnya akan bermuara kepada kesejahteraan masyarakat dan kemandirian daerah, serta penurunan terhadap ketergantungan pada pemerintah pusat. Namun menurut Yurianto, 2019 bahwa penerimann daerah tidak terlepas dari penerimaan daerah. Penerimaan daerah yang semakin tinggi maka semakin tinggi tingkat pengeluarannya untuk pembangunan. Pemerintah daerah pada era otonomi daerah mengharapkan mempercepat pembangunan daerah yang membutuhkan dana atau penerimaan daerah. Dengan kata lain pemerintah derah selain berusaha untuk meningkatkan PAD guan pembiayaan pembangunan daerahnya.

Berdasarkan pada uraian di atas muncul pertanyaan sampai seberapa besar pertumbuhan ekonomi dan PAD (Pendapatan Asli Daerah) Jakarta jika tidak ada pandemic covid 19. Dengan mengetahui PAD dan pertumbuhan ekonomi sebelum pandemic covid 19 dan membandingkan dengan angka PAD dan pertumbuhan ekonomi yang riil terjadi tahun 2020 maka akan bisa diketahui berapa nilai dampak pandemic covid 19 terhadap kedua indikator tersebut.

Sejalan dengan pemikiran tersebut, kajian ini dimaksudkan untuk menjawab beberapa pertanyaan berapa pengaruh belanja daerah pada APBD terhadap kinerja perekonomian daerah Provinsi DKI Jakarta. Dengan focus pada perhtiungan estimasi milai PAD dan pertumbuhan ekonomi Jakarta pada tahun 2020 jika tidak ada pandemic Covid 19. Pendekatan yang digunakan adalah pendekatan simultaneous equation model. 
Volume 12, No. 3, Desember 2020, pp. 230-242

e-ISSN: 2502-5449

p-ISSN: 2085-2266

DOI : 10.30998/sosioekons.v12i3.7568

Adapun maksud penelitian ini adalah untuk menganalisis estimasi pendapatan asli daerah dan pertumbuhan ekonomi Jakarta tahun 2020. Sedangkan secara rinci tujuan penelitian ini adalah:

1. Melakukan estimasi nilai PAD pada tahun 2020 tanpa ada pandemic covid 19

2. Melakukan estimasi pertumbuhan, ekonomi.tahun 2020 tanpa ada pandemic covid 19

\section{Studi Desentralisasi Fiskal}

Temuan Martinez-Vazquez dan McNab (2001) bahwa alasan mendasar di Negara berkembang untuk memilih desentralisasi fiskalnya adalah: (1) dengan adanya desentralisasi fiskal diharapkan pengeluaran pemerintah akan lebih lebih efisien . (2) dengan sentralisasi fiskal diakui telah mengalami kegagalan (3) peran pemerintah daerah akan lebih besar dan pemerintah daerah tidak didikte oleh pemeirntah pusat.

Berkaitan dengan pengeluaran pemerintah, menurut pendapat Todaro dan Smith (2006) bahwa pertumbuhan ekonomi negara atau wilayah sangat tergantung dari tingkat akumulasi modal yang meliputi semua bentuk atau jenis investasi baru yang dialokasikan dalam perekonomian. Sejalan dengan hal ini,, Simanjuntak (2010) menyatakan bahwa kebijakan otonomi daerah mempengaruhi tingkat kesejahteraan masyarakat tetapi tidak semua daerah memperoleh tingkat perbaikan kesejahteraan. Ini artinya pada daerah tertentu kebijakan fiskal tidak mempengaruhi kesejahteraan masyarakat. Selanjutnya dikatakan oleh Brodjonegoro, dalam Imamah (2018) bahwa kebijakan fiskal pada dasarnya merupakan suatu kebijakan ekonomi dalam rangka mengarahkan kondisi perekonomian untuk menjadi lebih baik dengan jalan mengubah penerimaan dan belanja pemerintah.

Pertumbuhan ekonomi dapat dilihat dari sisi permintaan dan sisi penawaran. Dalam konteks ini, dari sisi permintaan agregat, maka peningkatan output domestik dapat diidentifikasi dengan empat komponen perekonomian, yaitu : (1) pengeluaran konsumsi oleh rumahtangga (C), (2) pengeluaran investasi oleh dunia bisnis dan rumahtangga (I), (3) belanja pemerintah untuk barang dan jasa (G), dan (4) nett eksport (X-M) (Dornbusch, Fischer dan Startz, 2004

Selanjutnya pengelolaan keuangan daerah dan hubungan keuangan pusat daerah diatur dengan Undang-undang No 33 tahun 2004 tentang perimbangan keuangan pusat dan daerah. Pada penjelasan Undang-undang Nomor 33 Tahun 2004 antara lain diuraikan bahwa tujuan secara regulasi desentralisasi fiskal (1) memberikan keleluasaan kepada Daerah dalam menggali pendanaan dalam pelaksanaan otonomi daerah sebagai perwujudan asas desentralisasi; (2) membantu daerah dalam mendanai kewenangannya dan untuk mengurangi ketimpangan sumber pendanaan pemerintahan antara pusat dan daerah serta untuk mengurangi kesenjangan pendanaan pemerintahan antar daerah.

Sesuai dengan Undang undang No. 25 tahun 2004 tentang Sistem Perencanaan Pembangunan Nasional bahwa perencanaan pembangunan daerah diperoleh melalui proses pelibatan seluruh pemangku kepentingan pembangunan, yaitu pemerintah, masyarakat, dan dunia usaha yang prosesnya melalaui proses politik, teknokratik, partisipatif, top down dan bottom up. Hal ini sejalan dengan yang dikemukakan Siahaan dan Solomo, 2012. Pendapatnya mengatakan bahwa salah satu konsekuensi dari kebijakan otonomi daerah adalah adanya perubahan manajemen keuangan daerah. Dalam hal ini, bahwa sistem anggaran harus berbasis kinerja. Penyusunan dan pembahasan APBD dengan DPRD lebih difokuskan alokasi anggaran pada tiap Satuan Kerja Perangkat Daerah (SKPD) dan capaian keluaran (output) dan hasil (outcome) yang terukur untuk mencapai sasaran dan tujuan pemerintah daerah. Yang perlu mendapat perhatian adalah bahwa World Bank (2004) dalam Hasanah, Heni dan Siregar, 2014 juga menemukan bahwa pengeluaran publik di bidang kesehatan dan investasi infrastruktur lebih banyak memberikan manfaat untuk rumah tangga yang lebih mapan dan lebih berduit jika dibandingkan dengan rumah tangga miskin.

Dalam hal pendapatan di daerah dikenal dengan pendapatan asli daerah (PAD). pendapatan asli daerah terdiri atas pajak daerah, retribusi daerah, hasil pengelolaan kekayaan daerah yang 


\section{sosio e-kons}

Volume 12, No. 3, Desember 2020, pp. 230-242

e-ISSN: $2502-5449$

p-ISSN: 2085-2266

DOI : $10.30998 /$ sosioekons.v12i3.7568

dipisahkan dan lain lain pendapatan daerah yang sah. Secara perundangan pendapatan asli daerah adalah pendapatan yang diperoleh daerah yang dipungut berdasarkan Peraturan Daerah sesuai dengan peraturan perundang-undangan. Adapun tujuan dari adanya PAD itu adalah memberikan kewenangan kepada pemerintah daerah untuk mendanai pelaksanaan otonomi daerah sesuai dengan potensi daerah sebagai perwujudan desentralisasi.Semuanya ini dalam implementasinya memdomani Peraturan Pemerintah Nomor 58 Tahun 2005 tentang Pengelolaan Keuangan Daerah dan Peraturan Menteri Dalam Negeri No 13 Tahun 2006 tentang Pedoman Pengelolaan Keuangan Daerah,

Berkaitan dengan pengeluaran daerah secara umum bisa diklasifikasikan menjadi (1) pengeluaran pemerintah untuk kebutuhan barang dan jasa yang digunakan sekarang atau yang disebut dengan final consumption (2) pengeluaran pemerintah investasi yaitu pengeluaran pemerintah untuk pembangunan infrastuktur dan riset (3) pengeluaran pemerintah yang digunakan untuk produksi yang menggunakan faktor tenaga kerja yang berasal dari pemerintah itu sendiri dan penggunaan aset tetap dan pembelian barang dan jasa yang sifatnya antara. Selain itu, (4) pengeluaran pemerintah bisa digunakan untuk keperluan transfer dalam rangka pembiayaan kepentingan dan pengamanan sosial (Mankiw,2003).

Empat faktor yang mempengaruhi perkembangan pengeluaran pemerintah adalah (1) Perubahan permintaan akan barang publik. (2) Perubahan aktivitas pemerintah dalam menghasilkan barang publik. (3) Perubahan dari kombinasi faktor produksi yang digunakan dalam proses produksi barang publik, dan (4) Perubahan kualitas barang publik dan perubahan hargaharga faktor produksi (Mangkusubroto, 1998). Faktor faktor ini menjadi penting bagi penyusun kebijakan agar output yang dihasilkan dapat optimal dalam arti sesuai dengan kemampuan daerah dan kebutuhan daerah.

\section{METODE}

Data yang digunakan dalam penelitian ini adalah data sekunder dari berbagai sumber untuk periode 1987-2017. Sedangkan metode analisis yang akan digunakan dalam penelitian ini ada dua, yaitu analisis deskriptif dan analisis inferensia. Analisis deskriptif dalam penelitian ini digunakan untuk menggambarkan dan menginterpretasikan objek sesuai kondisi obyektif di lapangan.

Model persamaan simultan (simultaneous equation model) akan digunakan dalam penelitian ini. Dalam pengolahan data terkait analisis inferensia ini akan menggunakan software Statistical Analysis System/Estimation Time Series (SAS/ETS) versi 9.1.

\section{1) Spesifikasi Model}

Selanjutnya agar model dapat digunkan maka dilakukan spesifikasi model. Model yang digunakan adalah dengan pendeakatan ekonometrika. Model ekonometrika adalah suatu pola khusus dari model aljabar, yakni suatu unsur yang bersifat stochastic yang mencakup satu atau lebih peubah penggangguran. Model yang digunakan dalam studi ini adalah model persamaan simultan (Simultaneous Equation Model). Model persamaan simultan yang disusun terbagi menjadi lima blok dan terdiri dari 32 persamaan. Lima blok tersebut adalah Blok Fiskal Penerimaan Daerah, Blok Fiskal Pengeluaran Daerah, Blok PDRB, Blok Inflasi, dan Blok Indikator Sosial. Masing-masing blok terdiri dari persamaan strutkural dan persamaan identitas. Formulasi model secara umum dirumuskan sebagai berikut:

$$
\begin{aligned}
& Y_{i t}=\beta_{0}+\beta_{1} Y^{*}{ }_{i t}+\beta_{2} X_{i t}+\beta_{3} Z_{i t}+\beta_{4} Y_{i t-j}+u_{i t} \\
& \text { dimana } \\
& \begin{array}{ll}
\mathrm{i} \quad=1 \ldots \ldots \mathrm{N} \text { dan } \mathrm{t}=1 \ldots . \mathrm{T} \\
\mathrm{i} \quad=\text { menunjukkan dimensi cross section }
\end{array}
\end{aligned}
$$


Volume 12, No. 3, Desember 2020, pp. 230-242

e-ISSN: $2502-5449$

p-ISSN: 2085-2266

DOI : $10.30998 /$ sosioekons.v12i3.7568

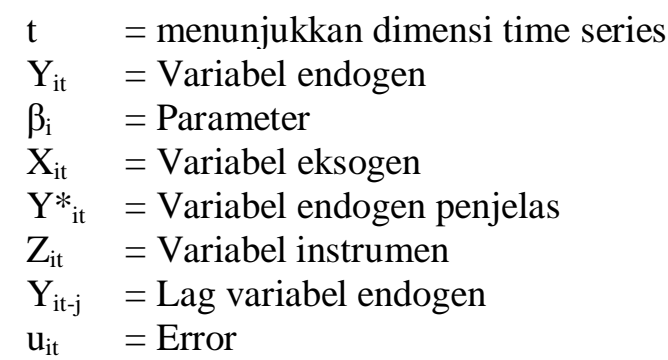

Blok Fiskal Penerimaan Daerah terdiri atas 13 persamaan dengan rincian 7 persamaan struktural dan 6 persamaan identitas. Blok Fiskal Pengeluaran Daerah teridri dari 4 persamaan dengan 3 persamaan struktural dan 1 persamaan identitas. Blok PDRB mempunyai 7 persamaan, tediri atas 5 persamaan struktural dan 2 persamaan identitas. Blok Inflasi tediri atas 4 persamaan, 3 persamaan struktural dan 1 persamaan identitas. sedangkan Blok Indikator Sosial tediri dari 4 persamaan, yang semuanya persamaan struktural. Secara rinci Blok dan persamaan dapat dilihat pada Lampiran 1.

Hubungan kelima blok dalam persamaan simultan tersebut dapat digambarkan dalam diagram berikut.

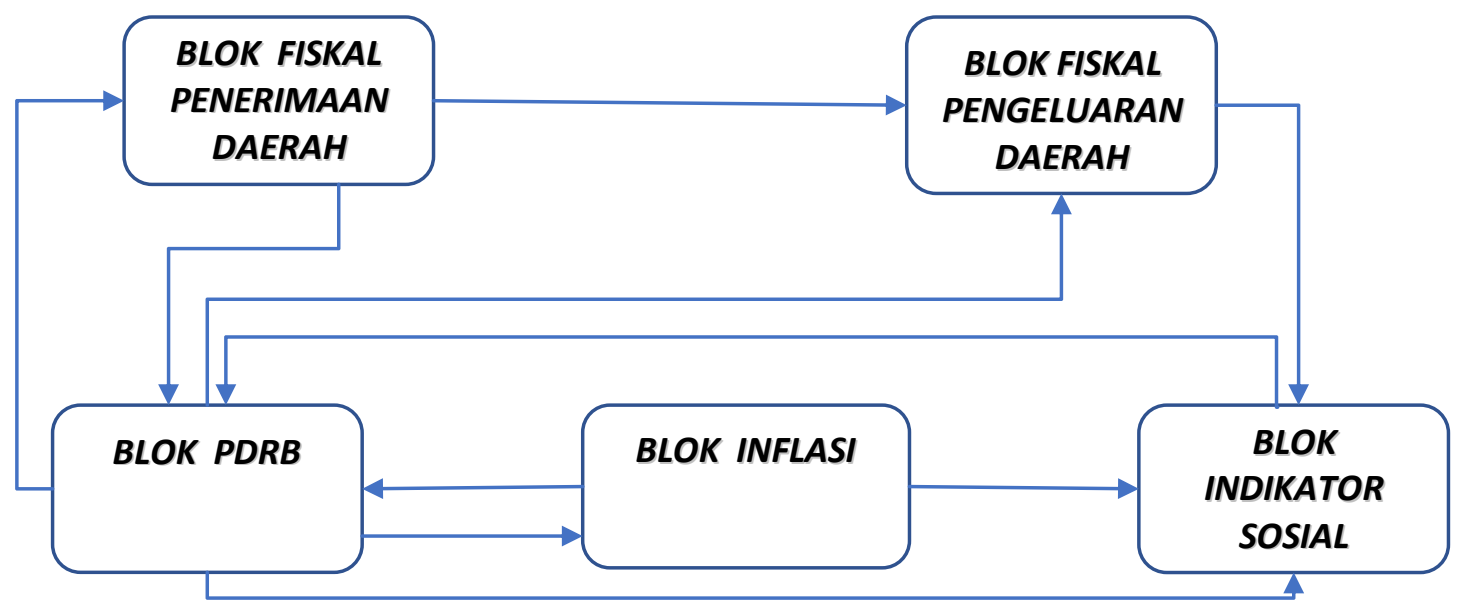

Gambar 1. Diagram Keterkaitan Antar Blok dalam Model Pengaruh Pengeluaran Pemerintah Pada APBD Terhadap Indikator Perekonomian DKI Jakarta

\section{2) Identifikasi Model dan Metode Estimasi}

Secara teori bahwa proses identifikasi terhadap suatu model dengan menggunakan model persamaan simultan merupakan langkah yang perlu untuk tujuan menentukan metode dalam mengestimasi parameter. Model persamaan simultan mensyaratkan jumlah persamaan harus sama dengan jumlah peubah endogen. Identifikasi model ditentukan atas dasar order condition sebagai syarat keharusan dan rank condition sebagai syarat kecukupan. Dalam hal ini bahwa menurut Koutsoyionis (1978), pendekatan ekonometrika dengan menggunakan sistem persamaan simultan mensyaratkan jumlah persamaan harus sama dengan jumlah variable endogen.

Menurut Gujarati (1995), syarat yang harus dipenuhi dalam proses identifikasi adalah order condition of identification yaitu bahwa jumlah variabel endogen dan eksogen yang tidak masuk dalam persamaan tetapi masuk dalam persamaan lain dalam sistem persamaan simultan tersebut harus sama dengan atau lebih besar dari jumlah variable endogen di dalam model dikurangi satu. Deskripsi tersebut dapat diformulasikan sebagai berikut: 
$(\mathrm{K}-\mathrm{M}) \geq(\mathrm{G}-1)$

Keterangan:

$\mathrm{K}=$ jumlah variabel dalam model (variabel endogen dan predetermined)

$\mathrm{M}=$ jumlah variabel endogen dan eksogen yang teradapat dalam persamaan yang diidentifikasi, dan

$\mathrm{G}=$ jumlah persamaan dalam model, yaitu sama dengan jumlah variable endogen dalam model

Berdasarkan order condition tersebut:

a. Jika $(\mathrm{K}-\mathrm{M})>(\mathrm{G}-\mathrm{M})$ maka persamaan disebut dikatakan persamaan teridentifikasi secara berlebih (overidentified).

b. Jika $(\mathrm{K}-\mathrm{M})=(\mathrm{G}-\mathrm{M})$ maka persamaan dikatakan terdientifiaksi secara tepat (just/exactly identified).

c. Jika $(\mathrm{K}-\mathrm{M})<(\mathrm{G}-\mathrm{M})$ maka persamaan dikatakan tidak teridentifikasi (unidentified).

Hanya persamaan yang exactly dan overidentified saja yang parameternya dapat diestimasi berdasarkan kriteria order condition tersebut.

\section{3) Validasi Model}

Validasi model dapat menggunakan indikator statistik Root Mean Square Percent Error (RMSPE). Formula statistik Root Mean Squares Percentage Error (RMSPE) dan Theil's Inequality Coefficeint (U-Theil) adalah sebagai berikut:

$$
\begin{aligned}
& R M S P E=\sqrt{\frac{1}{T} \sum_{t=1}^{T}\left(\frac{Y_{t}^{s}-Y_{t}^{\alpha}}{Y_{t}^{\alpha}}\right)^{2}} \times 100 \\
& U=\frac{\sqrt{\frac{1}{T} \sum_{t=1}^{T}\left(\Delta Y_{t}^{s}-\Delta Y_{t}^{a}\right)^{2}}}{\sqrt{\frac{1}{T} \sum_{t=1}^{T}\left(\Delta Y_{t}^{a}\right)^{2}}}
\end{aligned}
$$

Keterangan:

$\mathrm{T}=$ Jumlah periode (tahun) pengamatan

$\mathrm{Y}_{\mathrm{t}}^{\mathrm{s}}=$ Nilai estimasi pengamatan pada period ke-t

$\mathrm{Y}_{\mathrm{t}}^{\mathrm{a}}=$ Nilai pengamatan aktual pada periode ke- $\mathrm{t}$

Secara umum nilai indikator statistik dalam model menunjukkan bahwa nilai dugaannya tidak menyimpang dari nilai aktualnya sehingga cukup baik dilakukan simulasi. Dalam penelitian ini validadsi model akan menggunakan bantuan Software SAS/ETS versi 9.1. dengan perintah PROC SIMNLIN (Simulation Non Linear).

\section{4) Penyusunan Model dan Pembahasan}

Berdasarkan kriteria order condition, maka model adalah overidentified karena seluruh persamaan struktural yang ada dalam model adalah overidentified. Karena model adalah overidentified maka two-stage least squares (2SLS) merupakan prosedur estimasi yang sesuai untuk memperoleh nilai parameter struktural (Pyndyck dan Rubinfeld, 1998). Hasil estimasi secara lengkap dapat dilihat di Lampiran

Hasil estimasi dari model yang telah disusun selanjutnya dilakukan pengujian berdasarkan kriteria ekonomi, statistik dan ekonometrika. Nilai koefisien determinasi $\left(\mathrm{R}^{2}\right)$ setiap persamaan struktural berkisar antara 0,62 sampai dengan 0,99, kecuali untuk persamaan jumlah penduduk miskin (JUMIS) dan penerimaan retribusi (RET) yang bernilai masing-masing 0,32 dan 0,39 . 


\section{sosio e-kons}

Volume 12, No. 3, Desember 2020, pp. 230-242

e-ISSN: $2502-5449$

p-ISSN: 2085-2266

DOI : $10.30998 /$ sosioekons.v12i3.7568

Secara konsep, nilai statistik uji-F yang dihasilkan untuk menguji apakah variabelvariabel penjelas yang digunakan berpengaruh nyata terhadap variabel endogennya semuanya bernilai kurang dari 0,01 . Ini berarti variabel-variabel penjelas yang digunakan dalam model secara bersama-sama berpengaruh nyata terhadap variabel endogennya.

Hasil statistik uji-t untuk menguji apakah suatu variabel penjelas secara individu berpengaruh terhadap variabel endogennya atau tidak. Dengan tingkat kesalahan $(\alpha)$ sampai dengan 10 persen menunjukkan bahwa sebagian besar variabel penjelas secara individu berpengaruh nyata terhadap variabel endogennya. Namun terdapat beberapa variabel penjelas dalam model yang secara statistik tidak berpengaruh terhadap variabel endogennya.

\section{HASIL DAN PEMBAHASAN}

\section{Blok Fiskal Penerimaan Daerah \\ 1.1 Pendapatan Asli Daerah}

\section{a. Pajak Kendaraan Bermotor}

Hasil pendugaan parameter persamaan penerimaan pajak kendaraan bermotor bahwa penerimaan pajak kendaraan bermotor di DKI Jakarta dipengaruhi secara nyata oleh banyaknya kendaraan bermotor (JMKEND). Krisis ekonomi yang terjadi pada tahun 1998 juga berpengaruh terhadap penurunan penerimaan pajak kendaraan bermotor di DKI Jakarta.

Parameter dugaan JMKEND sebesar 0.726327 dan mempunyai hubungan yang positif. yang menunjukkan bahwa peningkatan JMKEND sebanyak seribu unit berpotensi meningkatkan penerimaan pajak kendaraan bermotor bagi Pemerintah Provinsi DKI Jakarta sebesar Rp. 726,3 juta. Ini menunjukkan bahwa meskipun masalah tumbuhnya kendaraan bermotor menyebabkan masalah seperti kemacetan, namun mempunyai pengaruh positif untuk memperbesar pendapatan yang diterima oleh pemerintah di daerah tersebut.

\section{b. Jumlah Kendaraan Bermotor}

Hasil pendugaan parameter persamaan jumlah kendaraan bermotor terlihat bahwa jumlah kendaraan bermotor di DKI Jakarta dipengaruhi secara nyata oleh produk domestik bruto (PDRB) dan harga eceran bahan bakar minyak (HECBBM).

Parameter dugaan PDRB sebesar 0.009393 dan mempunyai hubungan yang positif. yang menunjukkan bahwa peningkatan PDRB sebesar Rp 1 miliar berpotensi meningkatkan jumlah kendaraan bermotor di Provinsi DKI Jakarta sebanyak 9 unit. Ini menunjukkan bahwa peningkatan perekonomian di DKI Jakarta akan mendorong bertambahnya jumlah kendaraan. Sementara parameter dugaan HECBBM sebesar 0.888281 dan mempunyai hubungan yang positif. Hasil ini kurang sesuai dengan asumsi bahwa kenaikan harga eceran BBM akan menekan jumlah kendaraan bermotor. Hal ini kemungkinan disebabkan kenaikan harga eceran BBM tidak mempengaruhi minat orang untuk memiliki kendaraan bermotor baik karena sudah menjadi kebutuhan maupun karena kenaikan pendapatan masyarakat.

\section{c. Pajak Hotel dan Restoran}

Hasil pendugaan parameter persamaan penerimaan pajak hotel dan restoran bahwa penerimaan pajak hotel dan restoran di DKI Jakarta dipengaruhi secara nyata oleh pengeluaran konsumsi pemerintah (GOV) dan jumlah hotel, baik berbintang maupun non bintang (HOTEL).

Parameter dugaan GOV sebesar 0.015010 dan mempunyai hubungan yang positif. yang menunjukkan bahwa peningkatan GOV sebesar Rp 1 miliar berpotensi meningkatkan penerimaan pajak hotel dan restoran di Provinsi DKI Jakarta sebesar 
Rp. 15 juta. Ini menunjukkan bahwa peningkatan pengeluaran pemerintah di DKI Jakarta akan mendorong pengeluaran untuk penggunaan usaha hotel dan restoran.

Parameter dugaan HOTEL sebesar 4.387484 dan mempunyai hubungan yang positif. yang menunjukkan bahwa peningkatan jumlah hotel 1 unit berpotensi meningkatkan penerimaan pajak hotel dan restoran di Provinsi DKI Jakarta sebesar Rp. 4,39 juta. Ini menunjukkan bahwa perkembangan usaha akomodasi di DKI Jakarta akan mendorong peningkatan pajak hotel dan restoran.

\section{d. Penerimaan Bea Perolehan Hak atas Tanah dan Bangunan}

Hasil pendugaan parameter persamaan penerimaan bea perolehan hak atas tanah dan bangunan (BPHTB) bahwa penerimaan bea perolehan hak atas tanah dan bangunan di DKI Jakarta dipengaruhi secara nyata oleh nilai investasi (INV) dan jumlah penduduk (POP).

Parameter dugaan INV sebesar 0.005883 dan mempunyai hubungan yang positif. yang menunjukkan bahwa peningkatan investasi sebesar Rp 1 miliar berpotensi meningkatkan penerimaan BPHTB di Provinsi DKI Jakarta sebesar Rp. 5 juta. Ini menunjukkan bahwa peningkatan investasi di DKI Jakarta berpotensi meningkatkan penerimaan BPHTB.

Parameter dugaan POP sebesar 0.600467 dan mempunyai hubungan yang positif. yang menunjukkan bahwa peningkatan jumlah penduduk 1.000 orang berpotensi meningkatkan penerimaan BPHTB di Provinsi DKI Jakarta sebesar Rp. 600 juta. Ini dapat dijelaskan bahwa peningkatan penduduk berakibat naiknya kebutuhan atas tempat tinggal yang akan mendorong peningkatan peningkatan BPHTB

\section{e. Retribusi Daerah}

Selain pajak daerah, sumber pendapatan lain adalah retribusi daerah. Hasil pendugaan parameter persamaan penerimaan retribusi daerah bahwa penerimaan retribusi daerah di DKI Jakarta dipengaruhi secara nyata oleh jumlah kendaraan (JMKEND). Hal ini dapat dipahami peningkatan jumlah kendaraan berarti lebih banyak penerimaan pemerintah dari retribusi perparkiran.

Parameter dugaan JMKEND sebesar 0.024208 dan mempunyai hubungan yang positif. yang menunjukkan bahwa peningkatan jumlah kendaraan bermotor 1.000 unit berpotensi meningkatkan penerimaan retribusi Pemenrintah Provinsi DKI Jakarta sebesar Rp. 24,21 juta.

\subsection{Dana Perimbangan}

Selain berasal dari pendapatan asli daerah, Pemerintah Provinsi DKI Jakarta juga menerima transfer dana dari pemerintah pusat berupa dana perimbangan yang terdiri dari dana bagi hasil pajak dan bukan pajak serta dana alokasi umum. Dalam hal ini akan didekatai dengan dua variabel, yaitu variabel dana bagi hasil pajak dan dana bagi hasil bukan pajak.

\section{a. Bagi Hasil Pajak}

Hasil pendugaan parameter persamaan bagi hasil pajak disajikan pada Tabel 6. Pada Tabel 6 dapat dilihat bahwa penerimaan bagi hasil pajak Pemerintah provinsi DKI Jakarta dipengaruhi secara nyata oleh PDRB dan PBB.

Parameter dugaan PDRB sebesar 0.010791 dan mempunyai hubungan yang positif. yang menunjukkan bahwa peningkatan PDRB Rp 1 miliar berpotensi meningkatkan penerimaan dana bagi hasil pajak Pemenrintah Provinsi DKI Jakarta sebesar Rp. 10,79 juta. Sementara parameter dugaan PBB sebesar 1.380958 dan mempunyai hubungan yang positif. yang menunjukkan bahwa peningkatan PBB berpotensi meningkatkan penerimaan dana bagi hasil pajak Pemenrintah Provinsi 
DKI Jakarta. Namun beberapa tahun belakang PBB sudah menjadi pajak daerah tidak lagi dipungut pemerintah pusat.

\section{b. Bagi Hasil Bukan Pajak}

Hasil pendugaan parameter persamaan bagi hasil bukan pajak disajikan pada Tabel 7. Dari Tabel 7 dapat dilihat bahwa penerimaan bagi hasil bukan pajak Pemerintah Provinsi DKI Jakarta dipengaruhi secara nyata oleh PDRB. Parameter dugaan PDRB sebesar 0.000220 dan mempunyai hubungan yang positif. yang menunjukkan bahwa peningkatan PDRB Rp 1 miliar berpotensi meningkatkan penerimaan dana bagi hasil pajak Pemenrintah Provinsi DKI Jakarta sebesar Rp. 0,22 juta.

\section{Blok Fiskal Pengeluaran Daerah}

\subsection{Belanja Pegawai}

Hasil pendugaan parameter persamaan belanja pegawai bahwa pengeluaran belanja pegawai Pemerintah Provinsi DKI Jakarta dipengaruhi secara nyata oleh total penerimaan yang diterima pemerintah provinsi DKI Jakarta.

Parameter dugaan kapasitas fiskal sebesar 0.285348 dan mempunyai hubungan yang positif, yang berarti peningkatan penerimaan yang diterima Pemprov DKI Jakarta berpotensi meningkatkan belanja untuk pegawainya.

\subsection{Belanja Barang dan Jasa}

Hasil pendugaan parameter persamaan belanja barang dan jasa bahwa pengeluaran belanja barang dan jasa Pemerintah Provinsi DKI Jakarta dipengaruhi secara nyata oleh total penerimaan yang diterima pemerintah provinsi DKI Jakarta.

Parameter dugaan kapasitas fiskal sebesar 0.171371 dan mempunyai hubungan yang positif, yang berarti peningkatan penerimaan yang diterima Pemprov DKI Jakarta sebersar Rp 1 miliar berpotensi meningkatkan belanja untuk barang dan saja sebesar Rp 171 juta.

\subsection{Belanja Modal}

Hasil pendugaan parameter persamaan belanja modal disajikan bahwa pengeluaran belanja modal Pemerintah Provinsi DKI Jakarta dipengaruhi secara nyata oleh belanja barang dan jasa pemerintah provinsi DKI Jakarta.

Parameter dugaan belanja barang dan jasa sebesar 0.574626 dan mempunyai hubungan yang positif, yang berarti peningkatan belanja barang dan jasa Pemprov DKI Jakarta berpotensi meningkatkan belanja modal yang akan dikeluarkan Pemprov DKI Jakarta.

\section{Blok PDRB}

Dalam perekonomian produk domestik regional bruto (PDRB) sangat penting karena indikator ini dapat digunakan untuk mengukur kondisi perekonomian suatu daerah. Selain itu, PDRB juga merupakan salah satu indikator yang dapat digunakan untuk mengukur pertumbuhan ekonomi suatu negara, wilayah, atau daerah. Dalam teori makro ekonomi, PDB atau PDRB merupakan persamaan identitas dari konsumsi rumah tangga, investasi, pengeluaran pemerintah, ekspor dan impor. Blok PDRB terdiri dari persamaan Konsumsi Rumah Tangga, Investasi dan Pengeluaran Pemerintah

\section{Blok Inflasi, Suku Bunga dan Nilai Tukar}

\subsection{Indeks Harga Konsumen}

Hasil pendugaan parameter persamaan indeks harga konsumen (IHK) bahwa IHK dipengaruhi secara nyata oleh uang beredar, nilai tukar rupiah terhadap dolar Amerika Serikat, harga eceran BBM dan tarif dasar listrik.

Parameter dugaan uang beredar sebesar 0.000012 dan mempunyai hubungan yang positif, yang berarti meningkatnya jumlah uang beredar memicu kenaikan IHK dan berarti memicu inflasi. Sementara parameter dugaan nilai tukar rupiah terhadap 


\section{sosio e-kons}

Volume 12, No. 3, Desember 2020, pp. 230-242

e-ISSN: $2502-5449$

p-ISSN: 2085-2266

DOI : $10.30998 /$ sosioekons.v12i3.7568

dolar Amerika Serikat sebesar 0.003612 dan mempunyai hubungan yang positif, yang berarti melemahnya nilai tukar rupiah terhadap dolar Amerika Serikat dapat memicu inflasi. Ini dikarenakan melemahnya rupiah terhadap dolar Amerika Serikat menyebabkan harga di dalam negeri lebih mahal daripada barang luar negeri atau dengan kata lain terjadi kenaikan harga di dalam negeri.

Parameter dugaan harga eceran BBM sebesar 0.006888 dan mempunyai hubungan yang positif, yang berarti kenaikan harga BBM dapat memicu kenaikan IHK dan berarti memicu inflasi. Hal ini dikarenakan BBM merupakan salah satu sumber energy utama bagi dunia usaha, sehingga kenaikan harga BBM akan menyebabkan kenaikan biaya produksi. Akibatnya harga produk yang dihasilkan juga cenderung naik untuk menutupi biaya produksi.

Sementara parameter dugaan tarif dasar listrik sebesar 0.029826 dan mempunyai hubungan yang positif, yang berarti kenaikan tarif dasar listrik dapat memicu kenaikan IHK dan berarti memicu inflasi. Hal ini dikarenakan listrik merupakan salah satu sumber energi utama selain BBM bagi dunia usaha, sehingga kenaikan tarif dasar listrik akan menyebabkan kenaikan biaya produksi. Akibatnya harga produk yang dihasilkan juga cenderung naik untuk menutupi biaya produksi.

\subsection{Nilai Tukar Rupiah terhadap Dolar Amerika Serikat}

Hasil pendugaan parameter persamaan nilai tukar rupiah terhadap dolar Amerika Serikat bahwa fluktuasi nilai tukar rupiah terhadap dolar Amerika Serikat dipengaruhi secara nyata oleh indeks harga konsumen (IHK) dan nilai cadangan devisa yang miliki Indonesia.

Parameter dugaan IHK sebesar 134.9961 dan mempunyai hubungan yang positif, yang berarti terjadinya inflasi dapat memicu melemahnya nilai tukar rupiah terhadap dolar Amerika Serikat. Sementara parameter dugaan cadangan devisa sebesar 0.09111 dan mempunyai hubungan yang negatif, yang berarti meningkatnya cadangan devisa yang dimiliki Indonesia dapat memicu menguatnya nilai tukar rupiah terhadap dolar Amerika Serikat.

\subsection{Jumlah Uang Beredar}

Hasil pendugaan parameter persamaan uang beredar bahwa jumlah uang beredar di DKI Jakarta dipengaruhi nilai investasi (INV) di Provinsi DKI Jakarta dan suku bunga (SBI). Krisis ekonomi yang terjadi tahun 1998 juga berpengaruh terhadap peredaran uang di DKI Jakarta.

Parameter dugaan Investasi sebesar 5.518375 dan mempunyai hubungan yang positif, yang berarti kenaikan investasi dapat memicu kenaikan uang beredar. Ini dikarenakan kenaikan investasi berarti memerlukan uang yang lebih banyak, sehingga uang beredar juga naik. Sementara parameter dugaan SBI sebesar 36993.8 dan mempunyai hubungan yang negatif, yang berarti kenaikan suku bungan dapat memicu penurunan uang beredar. Ini dikarenakan kenaikan suku bunga dapat memicu masyarakat untuk menabung, sehingga uang beredar akan menurun.

Krisis ekonomi tahun 1998 juga berpengaruh terhadap kenaikan uang beredar. Hal ini dikarenakan pada saat krisis terjadi penarikan uang besar-besaran karena ketakutan kebangkrutan bank tempat mereka menyimpan uang, sehingga uang beredar di masyarakat meningkat tajam.

\section{Blok Indikator Sosial}

\subsection{Indeks Pembangunan Manusia}

Hasil pendugaan parameter persamaan indeks pembangunan manusia (IPM) bahwa IPM di DKI Jakarta dipengaruhi rata-rata lama sekolah. Parameter dugaan ratarata lama sekolah sebesar 3.008889 dan mempunyai hubungan yang positif, yang berarti 
kenaikan rata-rata lama bersekolah akan menaikan IPM. Hal ini dikarenakan rata-rata lama sekolah merupakan salah satu komponen penghitungan IPM.

\subsection{Jumlah Penduduk Miskin}

Hasil pendugaan parameter persamaan jumlah penduduk miskin bahwa jumlah penduduk miskin di DKI Jakarta dipengaruhi jumlah pengangguran. Krisis ekonomi tahun 1998 juga berpengaruh secara signifikan terhadap peningkatan jumlah penduduk miskin di DKI Jakarta.

Parameter dugaan jumlah pengangguran (UNEMP) sebesar 0.104685 dan mempunyai hubungan yang positif, yang berarti meningkatnya jumlah pengangguran akan memicu kenaikan jumlah penduduk miskin.

\subsection{Rata-rata Lama Sekolah}

Hasil pendugaan parameter persamaan rata-rata lama sekolah bahwa rata-rata lama sekolah penduduk DKI Jakarta dipengaruhi disposable income (DINCOME) dan tingkat pengangguran (RUEMP).

Parameter dugaan DINCOME sebesar 4.66E-6 dan mempunyai hubungan yang positif, yang berarti meningkatnya pendapatan masyarakat akan memicu kenaikan ratarata lama sekolah. Sementara parameter dugaan tingkat pengangguran sebesar 0.291460 dan mempunyai hubungan yang positif, yang berarti kenaikan tingkat pengangguran akan memicu kenaikan rata-rata lama sekolah.

\subsection{Jumlah Tenaga Kerja}

Hasil pendugaan parameter persamaan jumlah tenaga kerja bahwa jumlah tenaga kerja DKI Jakarta dipengaruhi PDRB dan jumlah angkatan kerja. Sementara krisis ekonomi tahun 1998 tidak mempengaruhi secara signifikan jumlah orang yang bekerja di DKI Jakarta.

Parameter dugaan PDRB sebesar 0.000899 dan mempunyai hubungan yang positif, yang berarti kenaikan PDRB akan menaikkan jumlah tenaga kerja yang terserap. Hal ini dikarenakan kenaikan kapasitas ekonomi akan membutuhkan tenaga kerja lebih banyak. Jumlah orang yang bekerja juga dipengaruhi jumlah angkatan kerja. Semakin meningkat jumlah angkatan kerja, maka orang yang bekerja juga semakin naik baik pada sektor formal maupun non formal.

Berdasrakan hasil analisis tersebut dan kaitannya dengan perhitungan nilai PAD dan pertumbuhan ekonomin Jakarta tahun 2020 tanpa ada pandemic covid 19 cukup prospektif. Pada tahun 2020 dengan asumsi normal tidak ada perubahan drastis baik karena faktor internal maupun eksternal baik nilai PAD mupun tingkat pertumbuhan ekonomi Jakarta cukup menjanjikan.

Tabel 1.

Perkiraan Nilai PAD, Pertumbuhan Ekonomi di Provinsi DKI Jakarta Tahun 2020

\begin{tabular}{llll}
\hline Variabel & Keterangan & Satuan & 2020 \\
\hline$(1)$ & $(2)$ & $(3)$ & $(4)$ \\
\hline PAD & Total PAD & Miliar Rp & $64.259,6$ \\
\hline GROWTH & Pertumbuhan ekonomi & Miliar Rp & 5,22 \\
\hline
\end{tabular}

Sumber: Hasil analisis, diolah 2020

Pada tahun 2020 tanpa ada pendemic Covid 19 , nilai PAD Jakarta diperkirakan sebesar Rp.64,26 triliun pada tahun 2020. Pertumbuhan ekonomi juga mengalami mencapai 5,22 persen. Sebetulnya perkiraan pertumbuhan ekonomi Jakarta juga cukup baik dan memberi harapan kepada perekonomian Jakarta. 


\section{SIMPULAN}

1. Berdasar kriteria ekonomi maupun statistik, model perekonomian DKI Jakarta yang disusun cukup representatif untuk menggambarkan keterkaitan antar variabel-variabel pendapatan maupun pengeluaran Pemprov DKI Jakarta, perekonomian, dan berbagai indikator sosial di DKI Jakarta. Berdasar hasil validasi, model yang disusun juga cukup valid digunakan untuk melakukan peramalan dan simulasi kebijakan.

2. Jika dampak pandemic covid19 tidak diperhitungkan maka diperkirakan total PAD pada tahun 2020 sebesar Rp.64,26 triliun dan pertumbuhan ekonomi juga diperkirakan akan tumbuh cukup baik, yaitu 5,22 persen.

3. Pengeluaran pemerintah berhubungan secara positif dengan kinerja PAD, dan pertumbuhan ekonomi. Artinya semakin tinggi pengeluaran pemerintah yang efektif maka akan semakin tinggi PAD dan pertumbuhan ekonommi.

\section{SARAN}

1. Diperlukan usaha yang antisipatif dan komprehensif berkaitan dengan penanggualangan dampak pandemic covid 19 terhadap perekonmian Jakarta. Hal ini mengingat dampaknya mulai tampak dari melemahnya daya beli masyarakat dan lesunya bisnis di Jakarta.

2. Kepada Penyusun APBD DKI Jakarta agar dalam mengalokasikan belanja harus selektif dan memfokuskan pada peningkatan belanja modal untuk menjaga agar perekonomian tetap tumbuh dan aspek kesehatan tetap terjaga. Alokasi belanja dikedepankan infrastruktur yang mendukung pulihnya komndisi Kesehatan amsyarakat.

3. Kepada Pemerintah agar memeberikan system merit dalam menegakkan aturan protocol Kesehatan. Bagi pelanggar harus dikenakan denda yang menjerakan dan bagi yang berhasil melaksanakan dengan baik maka perlu diberi reward yang sepadan.

\section{DAFTAR RUJUKAN}

Bappenas, (2017). Laporan Hasil Kajian Penyusunan Model Perencanaan Lintas Wilayah dan Lintas Sektor, Direktorat Kewilayahan I, Bappenas, Jakarta. Hal 39 s.d. 65.

Dornbusch, R., S. Fischer and R. Startz. (2004). Macroeconomics. Ninth Edition. The McGrawHill Company, New York.

Gujarati, D.N.(1995).Basic Econometric. Mc.Graw Hill.New York

Koutsoyiannis, A. (1977). Theory of Econometrics: An Introductory Exposition of Econometrics Methods. Second Edition. Harper and Row Publisher, London.

Mankiw, N.G. (2003). Macroeconomics. Fifth Edition. Worth Publisher, New York.

Martinez-Vazquez.J. dan M.R.Mc Nab.(2001). Decentralization Fiscal and Economic Growth. International Studies Working paper Series No. 97-7 Andrew Young Schools of Policies Studies. July.

Hasanah, Heni dan Hermanto Siregar. (2014). Pengaruh Belanja Pemerintah Daerah untuk kesejahteraan rakyat terhadap Penurunan Kemiskinan di Indonesia: Analisis Ekonometrika Panel Data Tingkat Provinsi. Prosiding Seminar Nasional \& Sidang Pleno ISEI XVII. Hal 255-264.

Mangkoesoebroto. G.(1998). Ekonomi Publik Badan Penerbit Fakultas Ekonomi Universitas Gajah Mada, Yogyakarta.

Pyndick,R.S.dan D.L.Rubinfeld. (1997). Econometric Model dan Economic Forecast, Fourth Edition. McGraw-Hill International Editions, Boston., Massachussets. 
Rodriguez-Pose, A. dan A. Kroijer. 2009. Fiscal Decentralization and Economic Growth in Central and Eastern Europe. LEQS Paper No. 12. London School of Economics and Political Science. October.

Simanjuntak, R. (2010). Desentralisasi Fiskal dan Manajemen Makroekonomi, Urgensi Suatu Grand Design di Indonesia. Prisma, 29 (3): 35-57.

Imamah, Nurul, (2018). Dampak Belanja Daerah terhadap Pertumbuhan Ekonomi: Pendekatan Persamaan Simultan. Jurnal Akuntansi dan Ekonomi FE. UN PGRI Kediri Vol. 3 No. 2, September 2018. ISSN: 2541-0180

Siahaan, Febi Christine, dan Roy Valiant Salomo. (2012). Alokasi Anggaran Belanja Sektor Transportasi dalam Anggaran Pendapatan dan Belanja Daerah Kota Depok tahun Anggaran 2006-2010. Jurnal Transportasi Vol 12 No. 1 April 2012 : 21-32.

Todaro, M. dan Stephen, S.C. (2006). Economic Development, Ninth Edition. Addison Wesley Harlow, Boston

Yurianto, (2019). Analisis Proyeksi Fiskal DKI Jakarta dengan Pendekatan Simultaneous Equation Model. Inovasi, Jurnal Ilmiah Ilmu Manajemen. Vol. 6. 2019 ISSN 2356-2005. Hal.21-40.

Undang Undang No: 25 tahun 2004 tentang System Perencanaan Pembangunan Nasional

Undang-Undang Nomor 33 Tahun 2004 tentang Perimbangan Keuangan antara Pemerintah Pusat dan Daerah.

Undang-Undang No 29 tahun 2007 tentang Pemerintahan Provinsi DKI Jakarta sebagai Ibukota Negara Kesatuan Republik Indonesia

Undang-Undang Nomor 23 Tahun 2014 tentang Pemerintahan Daerah

Peraturan Pemerintah Nomor 58 Tahun 2005 tentang Pengelolaan Keuangan Daerah.

Peraturan Menteri Dalam Negeri No 13 Tahun 2006 tentang Pedoman Pengelolaan Keuangan Daerah

https://bisnis.tempo.co/. 15 September 2020. DKI Sumbang 18 Persen PDB RI, BPS: PSBB Jakarta Berpengaruh Besar ke Ekonomi. https://bisnis.tempo.co/read/1386522/dkisumbang-18-persen-pdb-ri-bps-psbb-jakarta-berpengaruh-besar-ke-ekonomi 